Article

\title{
Synthesis of a New Polyanion Possessing Dense 1,2,3-Triazole Backbone
}

\author{
Linlin Xu, Yuri Kamon and Akihito Hashidzume * $\mathbb{D}$
}

Citation: Xu, L.; Kamon, Y.;

Hashidzume, A. Synthesis of a New Polyanion Possessing Dense 1,2,3-Triazole Backbone. Polymers 2021, 13, 1614. https://doi.org/ $10.3390 /$ polym 13101614

Academic Editor: Andrew B. Lowe

Received: 2 May 2021

Accepted: 14 May 2021

Published: 17 May 2021

Publisher's Note: MDPI stays neutral with regard to jurisdictional claims in published maps and institutional affiliations.

Copyright: (c) 2021 by the authors. Licensee MDPI, Basel, Switzerland. This article is an open access article distributed under the terms and conditions of the Creative Commons Attribution (CC BY) license (https:// creativecommons.org/licenses/by/ $4.0 /)$
Department of Macromolecular Science, Graduate School of Science, Osaka University, 1-1 Machikaneyama-cho, Toyonaka, Osaka 560-0043, Japan; xul18@chem.sci.osaka-u.ac.jp (L.X.); kamon@chem.sci.osaka-u.ac.jp (Y.K.)

* Correspondence: hashidzume@chem.sci.osaka-u.ac.jp; Tel.: +81-6-6850-8174

Abstract: Polyanions are an important class of water-soluble polymers because polyanions are utilized in a wide range of industrial fields. It is thus a great challenge to develop polyanions with novel structures to make their applications broader. In this study, a new polyanion with a dense 1,2,3triazole backbone, poly(4-azido-5-hexanoic acid) (poly(AH)), was synthesized by copper(I)-catalyzed azide-alkyne cycloaddition (CuAAC) polymerization of $t$-butyl 4-azido-5-hexanoate followed by hydrolysis of the $t$-butyl ester groups. Turbidimetric and potentiometric titration data indicated that poly $(\mathrm{AH})$ was well soluble in water under basic conditions $(\mathrm{pH}<7)$ and a weaker polyanion (apparent $\mathrm{p} K_{\mathrm{a}}=5.4$ ) than polyacrylic acid (apparent $\mathrm{p} K_{\mathrm{a}}=4.5$ ). Adsorption tests exhibited that sodium salt of poly $(\mathrm{AH})\left(\operatorname{poly}(\mathrm{AH}) \mathrm{Na}\right.$ ) adsorbed most preferably $\mathrm{Fe}^{3+}$ among the four metal ions examined, i.e., $\mathrm{Cu}^{2+}, \mathrm{Pb}^{2+}, \mathrm{Li}^{+}$, and $\mathrm{Fe}^{3+}$. ${ }^{1} \mathrm{H}$ spin-lattice relaxation time measurements indicated that $\mathrm{Fe}^{3+}$ ions were adsorbed favorably onto the 1,2,3-triazole residues.

Keywords: polyanion; dense 1,2,3-traizole polymer; copper(I)-catalyzed azide-alkyne cycloaddition polymerization; metal ion adsorption

\section{Introduction}

Polyanions are an important class of water soluble polymers showing various effects, e.g., thickening, gelling, dispersing, cohesive, adhesive, moisturizing, and metal-ion scavenging effects. On the basis of the effects, polyanions are thus utilized in a wide range of industrial fields including detergents, cosmetics, pharmaceuticals, foods, paints, textiles, civil engineering, and construction [1-6]. There are a number of polyanions, which are categorized into natural, semi-synthetic, and synthetic polymers. Polyanions are composed of the polymer backbone, anionic residues, and linkers between the backbone and anionic residues. Polyanions are used in appropriate applications depending on their properties based on the chemical structure. Therefore, it is a great challenge to develop polyanions with novel structures to make their applications broader.

1,2,3-Triazole is an aromatic five-membered ring consisting of two carbon and three nitrogen atoms with a large dipole $[7,8]$, which acts as an interaction site through hydrogen bonding, coordination bonding, dipole-dipole interaction, and $\pi-\pi$ stacking [8-14]. 1,2,3-Triazoles are readily formed from azide and alkyne functionalities through 1,3-dipolar cycloaddition [7,15-17]. In particular, it is known that 1,4-disubstituted 1,2,3-triazoles are formed efficiently and selectively in the presence of copper(I) compounds [18-20]. This reaction is known as copper(I)-catalyzed azide-alkyne cycloaddition (CuAAC). Because of its tolerance, $\mathrm{CuAAC}$ has been used in a variety of fields as the most important reaction in click chemistry [21,22]. CuAAC has been also utilized for synthesis of polymers possessing 1,2,3-triazole units [23-26]. We have been working on synthesis of polymers with the backbone composed of dense 1,2,3-triazole units by CuAAC polymerization of 3-azido-1-propyne (AP) and its derivatives [27-31]. Unfortunately, AP polymer was insoluble in all the solvents examined presumably because of strong dipole-dipole interaction of dense 1,2,3-triazole units. 
Recently, $t$-butyl 4-azido-5-hexanoate (tBuAH), which we designed and synthesized, was polymerized by $\mathrm{CuAAC}$ to yield a dense 1,2,3-triazole polymer soluble in organic solvents, including polar and halogenated ones, indicating that the $t$-butyl $(t$-Bu) ester side chains improved the solubility [32]. Since $t$-Bu ester is often used as a protecting group for carboxylic acid residue, a new polyanion, poly(4-azido-5-hexanoic acid) (poly(AH)), is obtained by hydrolysis of $t$-Bu ester, and the properties of poly $(\mathrm{AH})$ are investigated preliminarily in this study.

\section{Materials and Methods}

\subsection{Materials}

Tetrahydrofuran (THF), sodium (+)-ascorbate (NaAsc), ethylenediaminetetraacetic acid (EDTA), N,N-dimethylformamide (DMF), and dichloromethane (DCM) were purchased from FUJIFILM Wako Pure Chemical Corp. (Osaka, Japan). Trifluoroacetic acid (TFA), copper(I) bromide $(\mathrm{CuBr})$, and lithium chloride $(\mathrm{LiCl})$ were purchased from Nacalai Tesque Co., Ltd. (Kyoto, Japan). Lead(II) chloride $\left(\mathrm{PbCl}_{2}\right)$ and iron(III) nitrate $\left(\mathrm{Fe}\left(\mathrm{NO}_{3}\right)_{3} \cdot 9 \mathrm{H}_{2} \mathrm{O}\right)$ were purchased from Sigma-Aldrich (St. Louis, MO, USA). Water was purified with a Millipore Milli-Q system. Other reagents were used as received.

$t$-Butyl 4-azido-5-hexynoate ( $\mathrm{tBuAH})$ was prepared according to the procedure reported previously [32].

\subsection{Measurements}

${ }^{1} \mathrm{H}$ NMR spectra were measured on a JEOL JNM ECA400 spectrometer (JEOL Ltd., Tokyo, Japan) using tetramethylsilane (TMS) as an internal standard in $\mathrm{CDCl}_{3}$ as a solvent at $25^{\circ} \mathrm{C}$. Pulse-field-gradient spin-echo (PGSE) NMR data were obtained on a JEOL JNM ECA500 spectrometer (JEOL, Ltd., Tokyo, Japan) at $25^{\circ} \mathrm{C}$ using deuterium oxide $\left(\mathrm{D}_{2} \mathrm{O}\right)$ as a solvent. The bipolar pulse pair stimulated echo (BPPSTE) sequence was applied [33-35]. The strength of pulsed gradients $(g)$ was increased from 0.3 to 90 gauss $\mathrm{cm}^{-1}$. The time separation of pulsed field gradients $(\Delta)$ and their duration $(\delta)$ were 0.15 and $0.002 \mathrm{~s}$, respectively. The sample was not spun and the airflow was disconnected. The shape of the gradient pulse was rectangular, and its strength was varied automatically during the course of the experiments. Two-dimensional diffusion ordered spectroscopy (2D DOSY) data were obtained by inverse Laplace transformation using the SPLMOD method $[36,37] .{ }^{1} \mathrm{H}$ spinlattice relaxation times $\left(T_{1}\right)$ were determined using a conventional inversion recovery technique with a $180^{\circ}-\tau-90^{\circ}$ pulse sequence [38-40]. Size exclusion chromatography (SEC) analysis was carried out at $25^{\circ} \mathrm{C}$ on a TOSOH HLC-8320GPC system equipped with an RI detector and TOSOH TSK SuperAWM-H columns (TOSOH Corp. (Tokyo, Japan)), using dimethyl sulfoxide (DMSO) containing lithium bromide $\left(1.05 \mathrm{~g} \mathrm{~L}^{-1}\right)$ as the eluent at a flow rate of $0.4 \mathrm{~mL} \mathrm{~min}^{-1}$. The molecular weights were calibrated with seven standard samples of poly(ethylene glycol) (PEG) and poly(ethylene oxide) (PEO) (Scientific Polymer Products, Inc., Ontario, NY, USA)). The $M_{\mathrm{w}}$ values for standard samples were $9.6 \times 10^{2}, 1.45 \times 10^{3}$, $3.07 \times 10^{3}, 7.29 \times 10^{3}, 1.19 \times 10^{4}, 2.12 \times 10^{4}$, and $1.132 \times 10^{5}$. Sample solutions were filtrated with a DISMIC-13JP PTFE $0.50 \mu \mathrm{m}$ filter just prior to injection. Fourier transform infrared (FTIR) spectra were recorded on a JASCO FT/IR-4600 spectrometer (JASCO Corp., Tokyo, Japan) equipped with a JASCO ATR PRO ONE cell.

\subsection{Preparation of Poly(4-azido-5-hexynoic acid) (Poly $(A H))$}

A typical procedure for preparation of poly(AH) is described below (Scheme 1). 


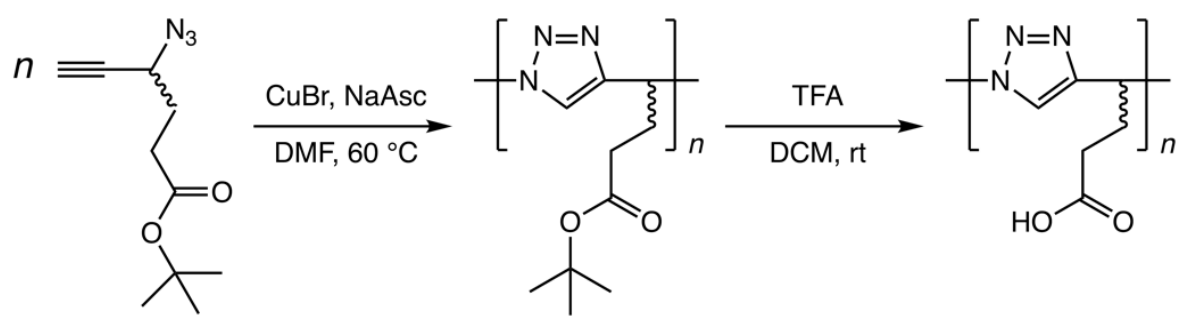

Scheme 1. Synthesis of poly $(\mathrm{AH})$ by $\mathrm{CuAAC}$ polymerization of $\mathrm{tBuAH}$ followed by hydrolysis of the $t$-Bu ester.

$\mathrm{CuBr}(39 \mathrm{mg}, 10 \%$ eq) and NaAsc (160 mg, 30\% eq) were added to a solution of tBuAH $(560 \mathrm{mg}, 2.7 \mathrm{mmol})$ in DMF $(0.2 \mathrm{~mL})$ under a nitrogen atmosphere. The reaction mixture was warmed using an oil bath thermostated at $60^{\circ} \mathrm{C}$ with stirring for $48 \mathrm{~h}$. After the reaction mixture was cooled down to room temperature, ethyl acetate $(20 \mathrm{~mL})$ was added to the mixture. The organic layer was washed with $0.50 \mathrm{M}$ EDTA $(2 \times 10 \mathrm{~mL})$ and with water $(100 \mathrm{~mL})$. The organic phase was dried with $\mathrm{Na}_{2} \mathrm{SO}_{4}$. The polymer obtained was recovered by reprecipitation with hexane $(60 \mathrm{~mL})$. The polymer was dried at $40{ }^{\circ} \mathrm{C}$ under reduced pressure (360 mg, 64\%). ${ }^{1} \mathrm{H}$ NMR $\left(\mathrm{CDCl}_{3}, 400 \mathrm{MHz}\right) \delta(\mathrm{ppm}): 7.94(1 \mathrm{H}, 1,2,3$-triazole $\mathrm{CH})$, $5.99(1 \mathrm{H}, \mathrm{CH}), 2.57\left(2 \mathrm{H}, \mathrm{CH}_{2}\right), 2.17\left(2 \mathrm{H}, \mathrm{CH}_{2}\right), 1.41\left(9 \mathrm{H}, t-\mathrm{C}_{4} \mathrm{H}_{9}\right)$.

The poly(tBuAH) sample ( $155 \mathrm{mg}, 0.74 \mathrm{mmol}$ monomer units) was dissolved in DCM $(3.7 \mathrm{~mL})$. TFA $(3.7 \mathrm{~mL})$ was added to the solution. The reaction mixture was stirred for $60 \mathrm{~min}$. The reaction mixture was diluted with methanol $(100 \mathrm{~mL})$ and the solvent was removed under reduced pressure to obtain the product, poly(AH). Poly(AH) was recovered as colorless solid after drying at $60{ }^{\circ} \mathrm{C}$ under reduced pressure $(112.6 \mathrm{mg}, 99 \%$ yield). ${ }^{1} \mathrm{H}$ NMR $\left(\mathrm{D}_{2} \mathrm{O}, 400 \mathrm{MHz}\right) \delta(\mathrm{ppm}): 8.35(1 \mathrm{H}, 1,2,3$-triazole $\mathrm{CH}), 6.06(1 \mathrm{H}, \mathrm{CH}), 2.62(2 \mathrm{H}$, $\left.\mathrm{CH}_{2}\right), 2.10\left(2 \mathrm{H}, \mathrm{CH}_{2}\right)$.

The poly( $\mathrm{AH})$ sample was then neutralized with an equimolar amount of $0.10 \mathrm{M}$ $\mathrm{NaOH}$, and the poly $(\mathrm{AH})$ neutralized (poly $(\mathrm{AH}) \mathrm{Na}$ ) was then recovered by drying under reduced pressure at $45^{\circ} \mathrm{C}$ for $12 \mathrm{~h}$.

\subsection{Turbidimetric and Potentiometric Titrations}

A sample of poly $(\mathrm{AH})$ not neutralized ( $68 \mu \mathrm{mol}$ monomer units) was dissolved in $0.10 \mathrm{M} \mathrm{NaOH}(780 \mu \mathrm{L})$ and then diluted with water $(5.4 \mathrm{~mL})$. While the polymer solution was titrated with $0.10 \mathrm{M} \mathrm{HCl}$ from $\mathrm{pH} 10.9$ using a microburet at $25^{\circ} \mathrm{C}$ under a nitrogen atmosphere, turbidity and $\mathrm{pH}$ were monitored after establishing the equilibrated state, in which the $\mathrm{pH}$ reached a constant value after each step of titrant addition. Turbidities, reported as 100-\%T, were measured with a Brinkmann PC920 probe colorimeter equipped with a $1 \mathrm{~cm}$ path length fiber optics probe at $620 \mathrm{~nm}$. Values of $\mathrm{pH}$ were measured with a Horiba F-23 pH meter equipped with a Horiba 9618S-10D glass electrode. The reference electrode was calibrated with buffer solutions of $\mathrm{pH} 4.01,6.86$, and 9.18 prior to $\mathrm{pH}$ measurements. The degrees of neutralization $(\alpha)$ were calculated from the amounts of the monomer unit and the added $\mathrm{HCl}$.

\subsection{Adsorption Tests}

Poly(AH)Na (11.5 mg, $65.7 \mu \mathrm{mol}$ monomer units) was added to an aqueous solution of a salt $\left(100 \mathrm{mg} \mathrm{L}^{-1}\right.$ metal ion), i.e., $\mathrm{PbCl}_{2}, \mathrm{CuSO}_{4} \cdot 5 \mathrm{H}_{2} \mathrm{O},\left(\mathrm{FeNO}_{3}\right)_{3} \cdot 9 \mathrm{H}_{2} \mathrm{O}$, or $\mathrm{LiCl}$, at $\mathrm{pH}=7$. The mixture was stirred at $35^{\circ} \mathrm{C}$ for $12 \mathrm{~h}$. After reaching equilibrium, $4 \mathrm{~mL}$ of the mixture solution was taken. The polymer-metal ion complexes were removed with a Pall Microsep ${ }^{\mathrm{TM}}$ advanced centrifugal device $1 \mathrm{~K}$ Omega (1 kDa cut off) by centrifugation at $1000 \mathrm{rpm}$ for $15 \mathrm{~min}$. The filtrate obtained $(1.2 \mathrm{~mL})$ was analyzed by a PerkinElmer Optima 8300 ICP-Optical Emission Spectroscopy system (PerkinElmer Inc. (Waltham, MA, USA)) to evaluate the equilibrium concentration $\left(c_{\mathrm{e}}\right)$ of metal ion. The concentrations of 
metal ions in the equilibrated state were reported as average values of three measurements. The removal ratio $\left(r_{\text {removal }}\right)$ and adsorption capacity $\left(q_{\mathrm{e}}\right)$ were calculated by

$$
\begin{gathered}
r_{\text {removal }}=\frac{100\left(c_{\mathrm{i}}-c_{\mathrm{e}}\right)}{c_{\mathrm{i}}} \\
q_{\mathrm{e}}=\frac{V\left(c_{\mathrm{i}}-c_{\mathrm{e}}\right)}{m}
\end{gathered}
$$

where $c_{\mathrm{i}}$ is the initial ion concentration, $m$ is the weight of poly(AH), and $V$ is the volume of solution.

\section{Results and Discussion}

\subsection{Synthesis and Structural Characterization of Poly $(A H)$}

In our previous study, we synthesized $\mathrm{tBuAH}$ possessing $t$-butyl $(t-\mathrm{Bu})$ ester in the side chain and conducted its CuAAC polymerization to obtain poly(tBuAH) with a dense 1,4-disubstituted 1,2,3-triazole backbone [32]. The unsubstituted dense 1,4-disubstituted 1,2,3-triazole polymer (poly(3-azido-1-propyne)) was insoluble in all the solvents studied, whereas poly (tBuAH) was soluble in many organic solvents, including polar and halogenated solvents, presumably because of the $t$-Bu ester moiety in the side chain. In this study, a new polyanion, poly( $\mathrm{AH})$, was synthesized by hydrolysis of the $t$-Bu ester moieties in poly(tBuAH). According to the procedure reported previously [32], tBuAH was polymerized by $\mathrm{CuAAC}$ to yield poly(tBuAH) consisting of 1,4-disubstituted 1,2,3-triazole residues. The $M_{\mathrm{W}}$ values for the poly $(\mathrm{tBuAH})$ samples obtained were determined to be $7.9 \times 10^{3}$ and $8.8 \times 10^{3}$, respectively, by SEC (Table 1$)$. The poly (tBuAH) samples were dissolved in DCM, and the $t$-Bu ester groups were hydrolyzed with TFA to synthesize poly(AH) samples. Since poly( $\mathrm{AH})$ is a weak polyanion possessing carboxylic acid moieties, the poly(AH) samples were neutralized with an equimolar amount of $\mathrm{NaOH}$ to dissolve in water and then recovered as a salt-type polymer samples (poly(AH)Na) by drying under reduced pressure.

Table 1. Basic characteristics of poly(tBuAH) samples prepared in this study.

\begin{tabular}{ccc}
\hline Sample & $\boldsymbol{M}_{\mathbf{w}} / \mathbf{1 0}^{\mathbf{3 1}}$ & $\boldsymbol{M}_{\mathbf{w}} / \boldsymbol{M}_{\mathbf{n}}{ }^{\mathbf{1}}$ \\
\hline${\text { poly }(\mathrm{tBuAH})^{2}}^{2}$ & 7.9 & 1.5 \\
poly(tBuAH) $^{3}$ & 8.8 & 1.4 \\
\hline
\end{tabular}

${ }^{1}$ Determined by SEC measurements at $25{ }^{\circ} \mathrm{C}$ using DMSO containing $1.05 \mathrm{~g} \mathrm{~L}^{-1} \mathrm{LiBr}$ as eluent. Molecular weights were calibrated with PEG and PEO standard samples. ${ }^{2}$ The poly(AH) sample prepared from this poly $(\mathrm{tBuAH})$ sample was used for the FTIR, turbidimetric and potentiometric titrations, and PGSE NMR. ${ }^{3}$ The poly(AH) sample prepared from this poly $(\mathrm{tBuAH})$ sample was used for the ${ }^{1} \mathrm{H} N M R$, adsorption tests, and $T_{1}$ measurements.

Poly(AH) was characterized by ${ }^{1} \mathrm{H}$ NMR and FTIR. Figure 1 shows ${ }^{1} \mathrm{H}$ NMR spectra for poly(tBuAH) and poly(AH). As can be seen in Figure 1a, the spectrum of poly(tBuAH) in $\mathrm{CDCl}_{3}$ contains signals ascribable to the proton in 1,4-disubstituted 1,2,3-triazole and the methine proton in the main chain at ca. 7.9 and $6.0 \mathrm{ppm}$, respectively. The signals at ca. 2.6 and $2.2 \mathrm{ppm}$ are assignable to the protons of two methylenes in side chain. The signal due to the $t$-Bu ester was observed at ca. $1.4 \mathrm{ppm}$. This ${ }^{1} \mathrm{H}$ NMR spectrum is thus indicative of successful preparation of poly(tBuAH) consisting of 1,4-disubstituted 1,2,3-triazole units. In the spectrum of poly $(\mathrm{AH})$ in $\mathrm{D}_{2} \mathrm{O}$ (Figure $1 \mathrm{~b}$ ), on the other hand, signals due to protons of the triazole, methine, and methylenes were observed, whereas the signal ascribable to the $t$-Bu ester was not observed. These observations indicate that poly(AH) was successfully obtained through quantitative hydrolysis of the $t$-Bu ester groups, as can be seen in Scheme 1. 


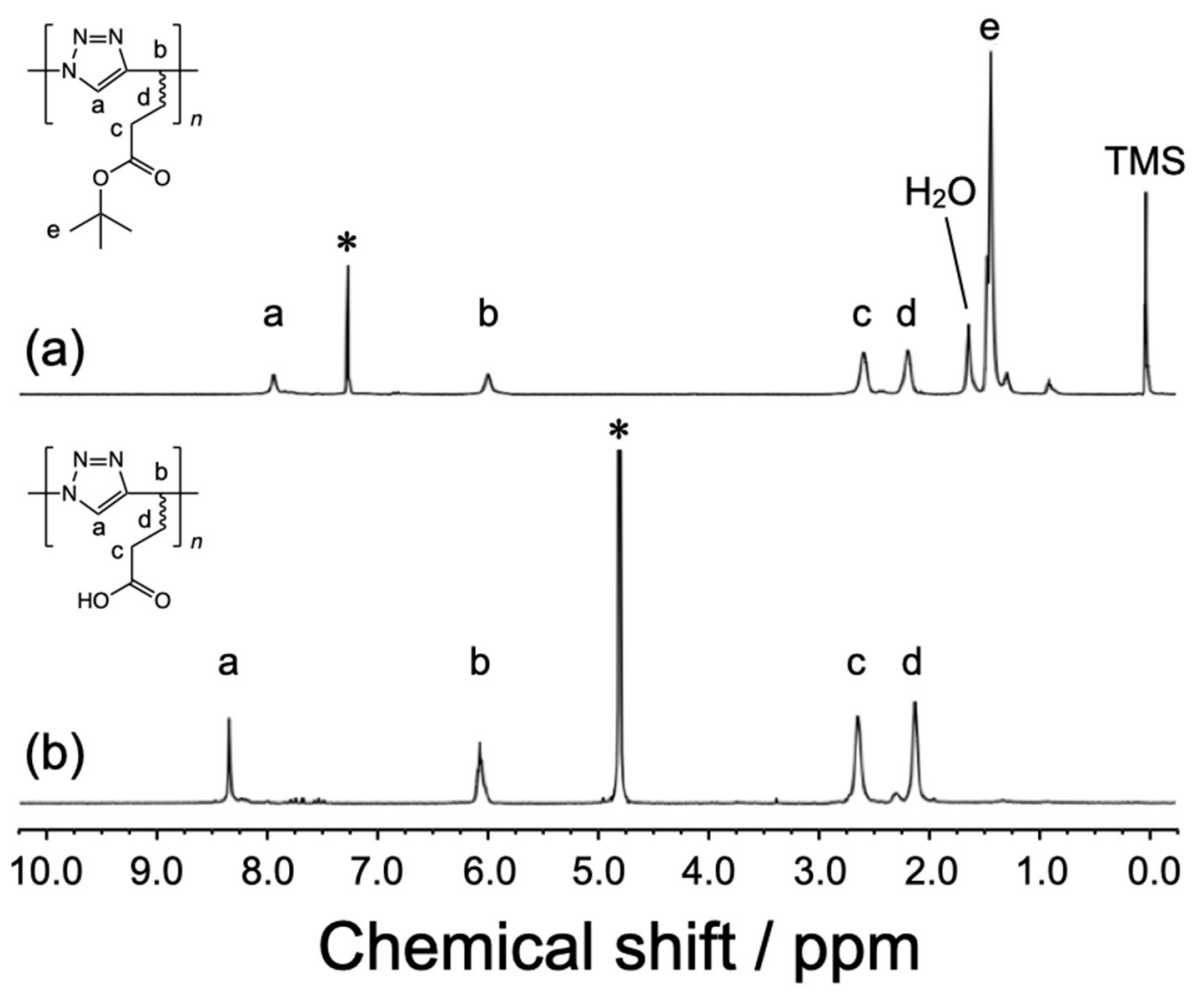

Figure 1. ${ }^{1} \mathrm{H}$ NMR spectrum for poly $(\mathrm{tBuAH})\left(\mathrm{CDCl}_{3}\right)(\mathbf{a})$ and poly $(\mathrm{AH})\left(\mathrm{D}_{2} \mathrm{O}\right)(\mathbf{b})$. Assignments are indicated as a, b, c, d, and e. Asterisks denote the signals due to the residual protons in solvents.

Figure 2 shows FTIR spectra of poly(tBuAH) and poly(AH). Both the spectra indicate absorption bands ascribable to 1,2,3-triazole at ca. 1500,1000, and $800 \mathrm{~cm}^{-1}$. In the spectrum of poly(tBuAH), the signal attributed to the stretching vibration of the ester carbonyl was observed around $1720 \mathrm{~cm}^{-1}$, whereas in the spectrum of poly(AH), a broad signal attributed to the carboxylic acid was observed around $1692 \mathrm{~cm}^{-1}$. It should be noted here that the spectrum of poly $(\mathrm{AH})$ contains a broad absorption band ascribable to the stretching vibration of $\mathrm{O}-\mathrm{H}$ in the region of $2500-3500 \mathrm{~cm}^{-1}$ caused by intermolecular hydrogen bonding. These FTIR spectra also confirm that poly(AH) was successfully obtained by quantitative hydrolysis of the $t$-Bu ester groups in the side chain of poly $(\mathrm{tBuAH})$ while the dense 1,2,3-triazole backbone was maintained.

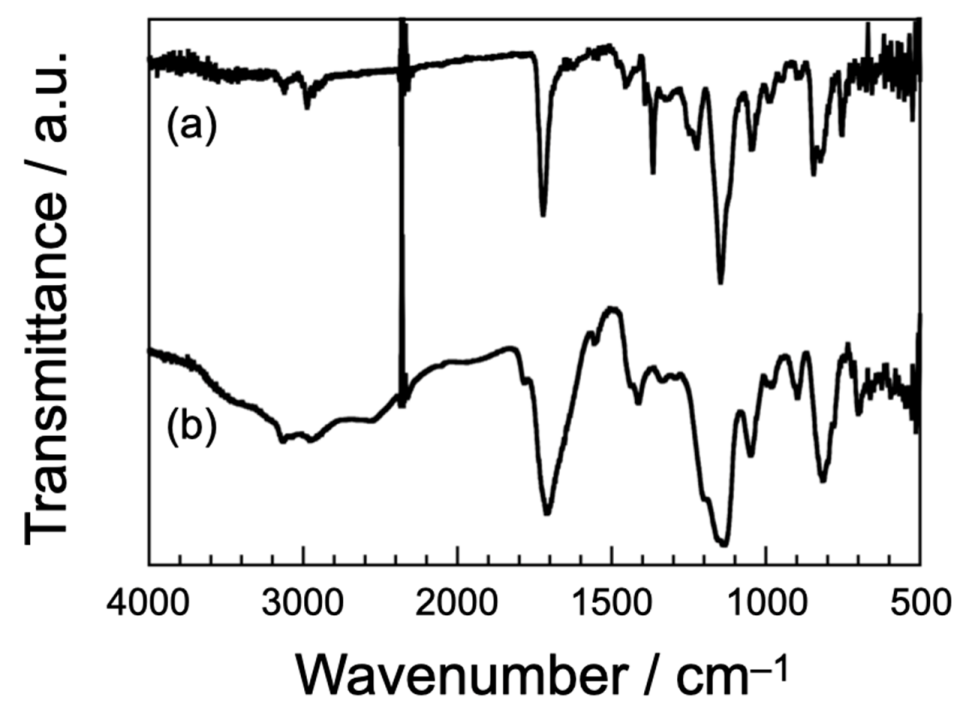

Figure 2. FTIR spectrum for poly(tBuAH) (a) and poly(AH) (b). 


\subsection{Turbidimetric and Potentiometric Titrations}

Turbidimetric and potentiometric titrations were carried out to study basic characteristics of poly(AH) as polyanion in aqueous media. The acid form of poly $(\mathrm{AH})(10.4 \mathrm{mg}$, $68 \mu \mathrm{mol}$ monomer units) and a small excess of $\mathrm{NaOH}(0.10 \mathrm{M}, 780 \mu \mathrm{L})$ were dissolved in water $(5.4 \mathrm{~mL})$. Values of turbidity and $\mathrm{pH}$ were recorded while hydrochloric acid $(0.10 \mathrm{M})$ was added with a microburet to the polymer aqueous solution as a titrant with stirring under a nitrogen atmosphere. The dissociation degrees $(\alpha)$ were calculated using the mass of poly(AH) and the amount of $\mathrm{HCl}$ added, and the values of turbidity and $\alpha$ were plotted in Figure 3 against $\mathrm{pH}$. As can be seen in Figure 3, the turbidity was almost 10\% at $\mathrm{pH}>7$, whereas the turbidity increased with decreasing $\mathrm{pH}$ from 7 to 4 and then saturated at ca. $90 \%$ in the regime of $\mathrm{pH}<4$. On the other hand, $\alpha$ decreased with decreasing $\mathrm{pH}$ and reached 0 at ca. $\mathrm{pH}=3$. The apparent $\mathrm{p} K_{\mathrm{a}}$ at which $\alpha=0.5$ was estimated to be ca. 5.4 , which is larger than that of polyacrylic acid (PAA) $\left(\mathrm{p} K_{\mathrm{a}}=4.5\right)$ [41]. This observation indicates that poly $(\mathrm{AH})$ is a weaker polyanion than PAA presumably because of the more hydrophobic backbone and linker of poly( $\mathrm{AH})$ [42].

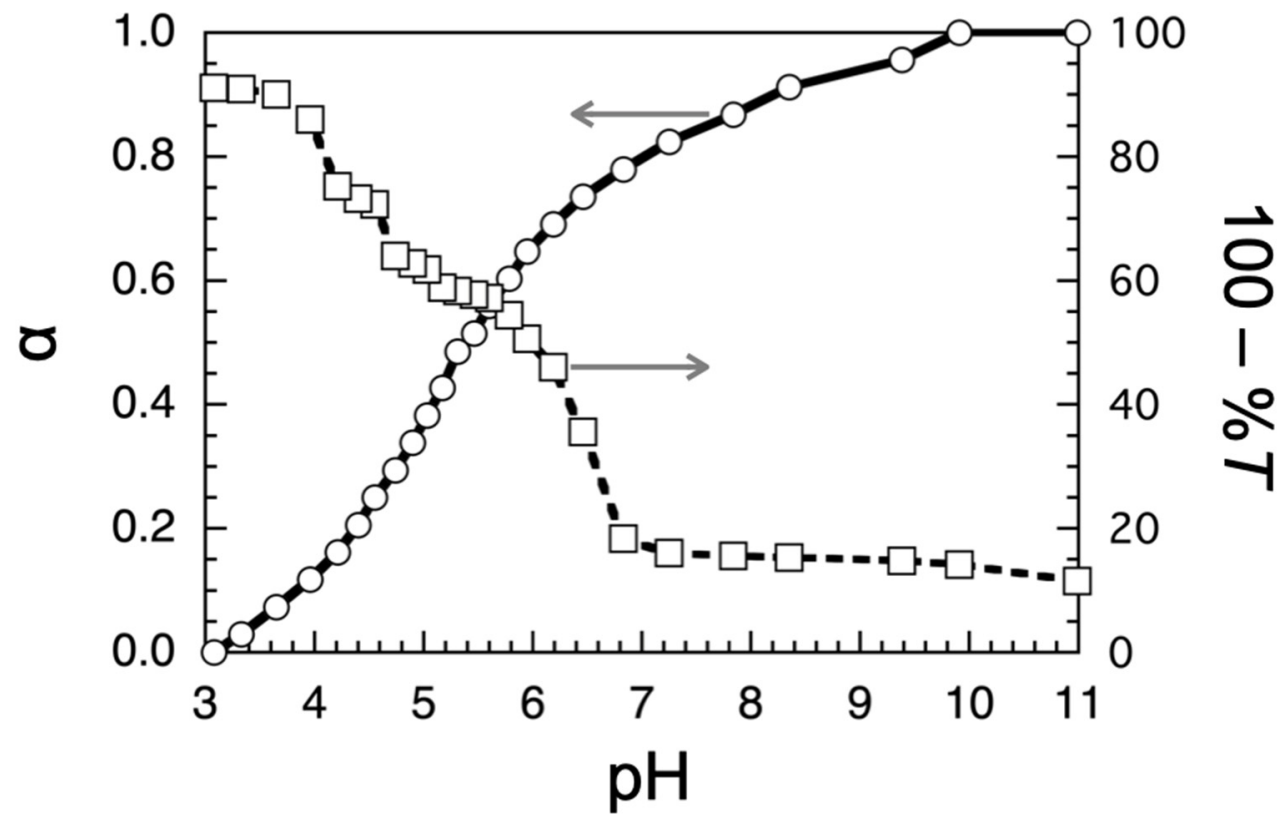

Figure 3. Turbidimetric and potentiometric titration data for an aqueous solution of poly(AH). The titration was performed by stepwise addition of $30 \mu \mathrm{L}$ of $0.10 \mathrm{M} \mathrm{HCl}$ starting from $\mathrm{pH}$ 9.9.

\subsection{Pulse-Field-Gradient Spin-Echo NMR}

The molecular sizes of poly(AH) chains in aqueous solution at $\mathrm{pH} 9.0$ and 12.0 (i.e., pD 9.4 and 12.4, respectively) were estimated by PGSE NMR using $\mathrm{D}_{2} \mathrm{O}$ containing $5 \mathrm{mM} \mathrm{NaCl}$ as a solvent. As can be seen in Figure 4, 2D DOSY data indicate that all the signals for poly(AH) were observed as unimodal distribution in the mutual diffusion coefficient $(D)$ region of $(4.5-6.5) \times 10^{-11}$ and $(4-9) \times 10^{-11} \mathrm{~m}^{2} \mathrm{~s}^{-1}$ at $\mathrm{pH} 9.0$ and 12.0, respectively. (Here, the signals for methylene protons at ca. $2.2 \mathrm{ppm}$ were not observed because the signals were very close to that for acetonitrile, the internal standard.) Using the signal attributed to the main-chain methine proton, the $D$ values were evaluated to be $5.2 \times 10^{-11}$ and $4.7 \times 10^{-11} \mathrm{~m}^{2} \mathrm{~s}^{-1}$ at $\mathrm{pH} 9.0$ and 12.0 , respectively. On the basis of these $D$ values, the hydrodynamic radii values were calculated to be ca. 3.4 and $3.7 \mathrm{~nm}$ at pH 9.0 and 12.0, respectively, using the Einstein-Stokes equation. These data indicate that poly $(\mathrm{AH})$ takes a conformation independent of $\mathrm{pH}$ under basic conditions. 

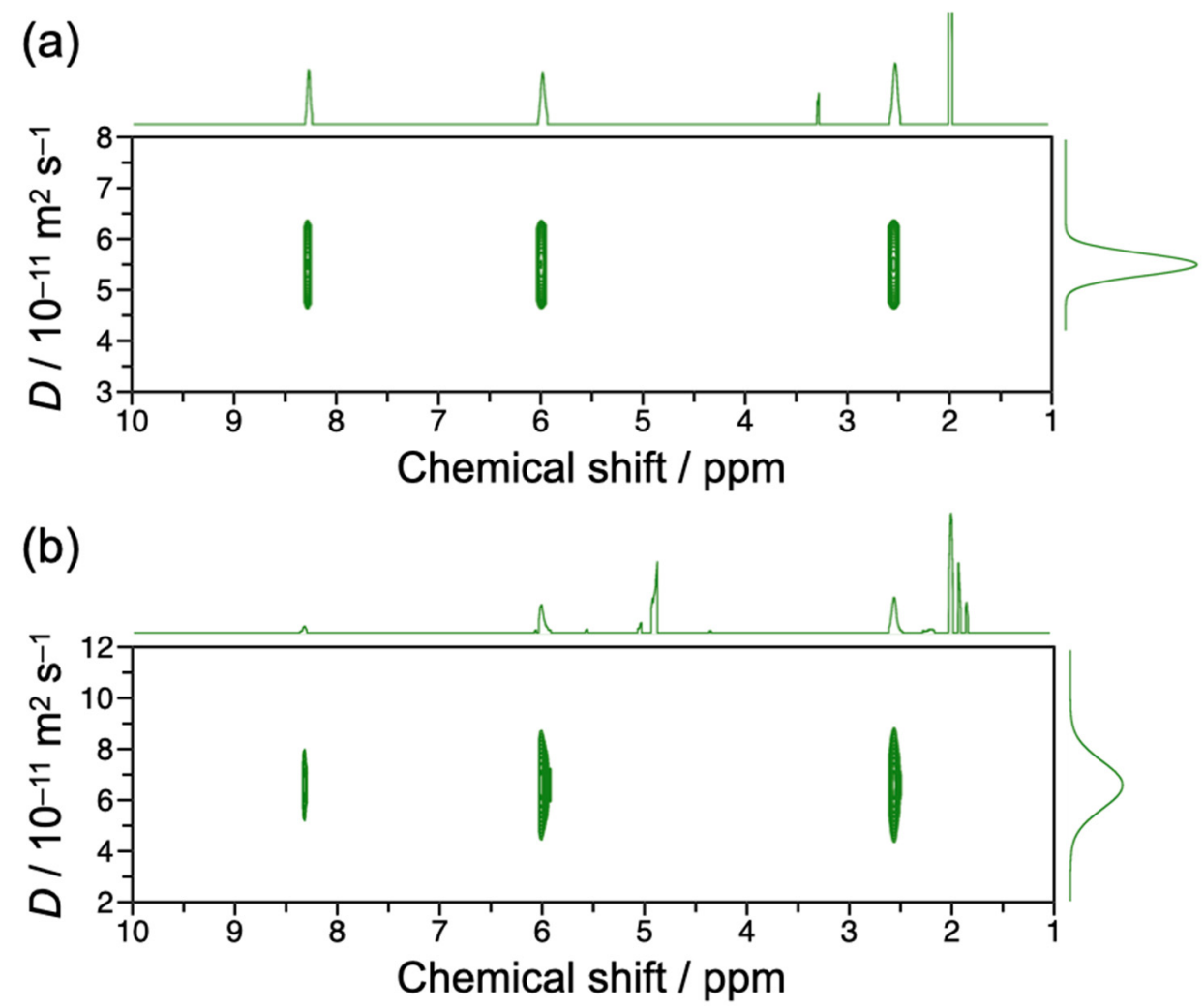

Figure 4. 2D DOSY data for poly(AH)Na in $\mathrm{D}_{2} \mathrm{O}$ containing $5 \mathrm{mM} \mathrm{NaCl}$ at $\mathrm{pH} 9.0$ (a) and 12.0 (b).

\subsection{Adsorption Tests}

Poly(AH)Na possesses 1,2,3-triazole and carboxylate moieties in the monomer unit. Since 1,2,3-triazole and carboxylate moieties may act as relatively soft and hard ligands, respectively, poly $(\mathrm{AH}) \mathrm{Na}$ may coordinate metal ions. Adsorption tests were thus performed using poly(AH)Na. Four salts, i.e., $\mathrm{CuSO}_{4} \cdot 5 \mathrm{H}_{2} \mathrm{O}, \mathrm{PbCl}_{2}$, $\mathrm{LiCl}$, and $\mathrm{Fe}\left(\mathrm{NO}_{3}\right)_{3}$, were added to an aqueous solution of poly $(\mathrm{AH}) \mathrm{Na}$, stirred for $12 \mathrm{~h}$ to reach adsorption equilibrium, and then the polymer was removed by centrifugal filtration. The equilibrium concentrations $\left(c_{\mathrm{e}}\right)$ of metal ions were determined by ICP measurements. Using the $c_{\mathrm{e}}$ value of metal ion, the removal ratio $\left(r_{\text {removal }}\right)$ and the amount of metal ion adsorbed on $1.0 \mathrm{~g}$ of poly $(\mathrm{AH}) \mathrm{Na}$ (adsorption capacity, $q_{\mathrm{e}}$ ) were evaluated, as summarized in Table 2. The $q_{\mathrm{e}}$ values were $75.12 \pm 0.02,62.0 \pm 0.2,89.22 \pm 0.02$, and $98.57 \pm 0.03 \mathrm{mg} \mathrm{g}^{-1}$ for the four metal ions used, i.e., $\mathrm{Cu}^{2+}, \mathrm{Pb}^{2+}, \mathrm{Li}^{+}$, and $\mathrm{Fe}^{3+}$, respectively (Figure 5). (Under the conditions in this study, the $r_{\text {removal }}$ values were almost the same as the $q_{\mathrm{e}}$ values; $75.10 \pm 0.02,62.0 \pm 0.2,89.20 \pm 0.02$, and $98.54 \pm 0.03 \%$ for $\mathrm{Cu}^{2+}, \mathrm{Pb}^{2+}, \mathrm{Li}^{+}$, and $\mathrm{Fe}^{3+}$, respectively.) These observations indicate that poly(AH)Na can be used as an adsorbent for metal ions, especially $\mathrm{Fe}^{3+}$ ion.

Table 2. Removal percentages $\left(r_{\text {removal }}\right)$ and adsorption capacities $\left(q_{\mathrm{e}}\right)$ of poly(AH)Na for metal ions.

\begin{tabular}{ccccc}
\hline Metal Ion & $c_{\mathrm{i}} / \mathbf{m g ~ L}^{-\mathbf{1}}$ & $\boldsymbol{c}_{\mathrm{e}} / \mathbf{m g ~ L}^{-\mathbf{1}}$ & $\boldsymbol{r}_{\text {removal }} / \mathbf{\%}$ & $\boldsymbol{q}_{\mathrm{e}} / \mathbf{m g ~ g}^{\mathbf{- 1}}$ \\
\hline $\mathrm{Cu}^{2+}$ & 100 & $24.90 \pm 0.02$ & $75.10 \pm 0.02$ & $75.12 \pm 0.02$ \\
$\mathrm{~Pb}^{2+}$ & 100 & $38.0 \pm 0.2$ & $62.0 \pm 0.2$ & $62.0 \pm 0.2$ \\
$\mathrm{Li}^{+}$ & 100 & $10.80 \pm 0.02$ & $89.20 \pm 0.02$ & $89.22 \pm 0.02$ \\
$\mathrm{Fe}^{3+}$ & 100 & $1.46 \pm 0.03$ & $98.54 \pm 0.03$ & $98.57 \pm 0.03$ \\
\hline
\end{tabular}




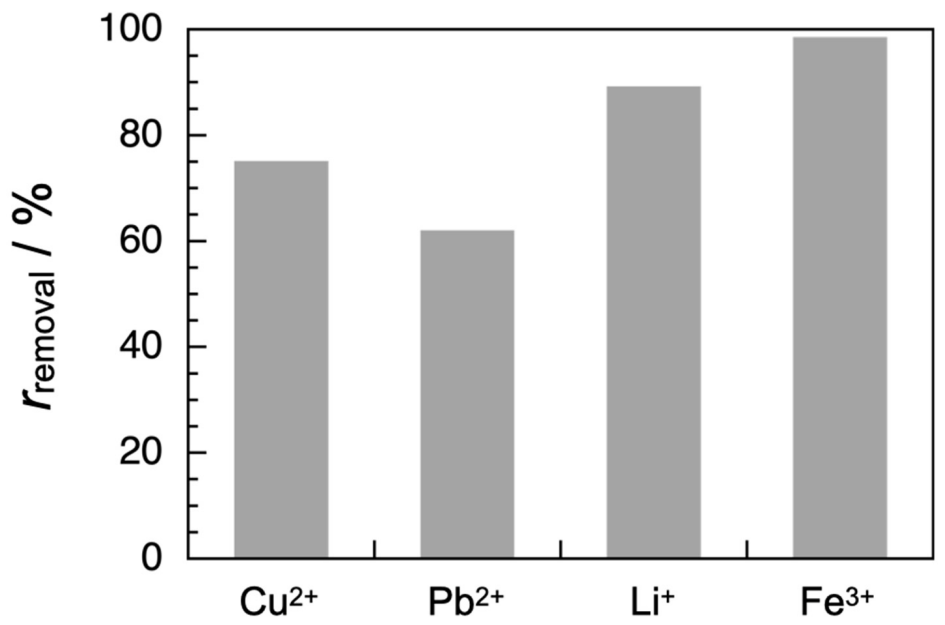

Figure 5. Removal ratio of poly( $\mathrm{AH}) \mathrm{Na}$ for $\mathrm{Cu}^{2+}, \mathrm{Pb}^{2+}, \mathrm{Li}^{+}$, and $\mathrm{Fe}^{3+}$.

Since $\mathrm{Fe}^{3+}$ is a paramagnetic species, NMR relaxation may be significantly faster in the presence of $\mathrm{Fe}^{3+}$. Figure 6 displays ${ }^{1} \mathrm{H}$ NMR spectra for poly(AH)Na in the presence of varying concentrations of $\mathrm{Fe}\left(\mathrm{NO}_{3}\right)_{3}$. The signals due to poly(AH)Na are only slightly broader at $\left[\mathrm{Fe}^{3+}\right]=0.1 \mathrm{mM}$. At $\left[\mathrm{Fe}^{3+}\right]=3.1$ and $9.1 \mathrm{mM}$, on the other hand, the ${ }^{1} \mathrm{H} \mathrm{NMR}$ spectra show markedly broader signals. It should be noted here that the signals due to the triazole and methine protons at ca. 8.2 and $6.0 \mathrm{ppm}$ became weaker than did the signals due to the methylene protons at ca. 2.2. and $2.6 \mathrm{ppm}$. $T_{1}$ values of signals were measured and compared in ${ }^{1} \mathrm{H}$ NMR spectra in the presence and absence of $0.6 \mathrm{mM} \mathrm{Fe}^{3+}$ (Table 3). Figure 7 indicates the ratios of $T_{1}$ values for the ${ }^{1} \mathrm{H}$ NMR signals in the presence and absence of $0.6 \mathrm{mM} \mathrm{Fe}^{3+}$. The ratio was $80.4 \%$ for the triazole proton at ca. $8.2 \mathrm{ppm}$, whereas those were $90.0-96.6 \%$ for the methine $(6.0 \mathrm{ppm})$ and methylene protons ( 2.6 and $2.0 \mathrm{ppm})$. These observations indicate that $\mathrm{Fe}^{3+}$ ions are adsorbed more preferably onto the 1,2,3-triazole residues $[43,44]$.

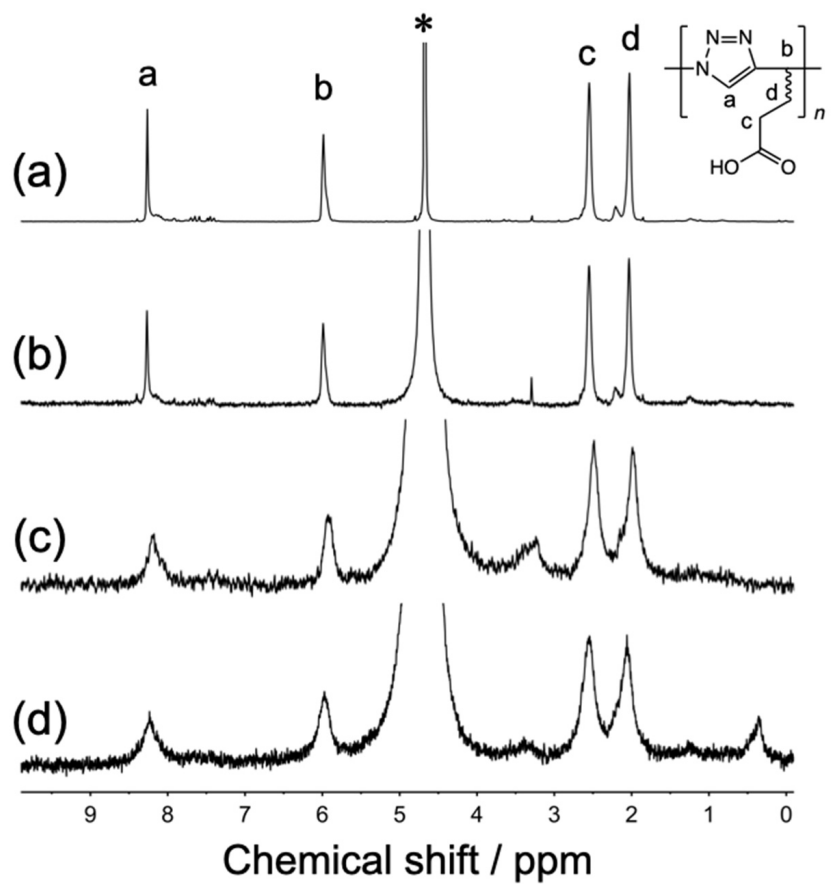

Figure 6. ${ }^{1} \mathrm{H}$ NMR spectrum for poly(AH)Na in the absence (a) and presence of $0.1(\mathbf{b}), 3.1(\mathbf{c})$, and $9.1 \mathrm{mM}$ of $\mathrm{Fe}\left(\mathrm{NO}_{3}\right)_{3}\left(\mathrm{D}_{2} \mathrm{O}\right)(\mathbf{d})$. Assignments are indicated as $\mathrm{a}, \mathrm{b}$, c, and d. Asterisks denote the signals due to the residual protons in solvents. 
Table 3. ${ }^{1} \mathrm{H}$ NMR chemical shifts and $T_{1}$ values for poly(AH)Na in the absence and presence of $0.6 \mathrm{mM} \mathrm{Fe}\left(\mathrm{NO}_{3}\right)_{3}$.

\begin{tabular}{cccc}
\hline$\delta / \mathbf{p p m}$ & $\boldsymbol{T}_{\mathbf{1}, \mathbf{p A H}}{ }^{\mathbf{1} / \mathbf{s}}$ & $\boldsymbol{T}_{\mathbf{1}, \mathbf{p A H F e}}{ }^{2} / \mathbf{s}$ & $\boldsymbol{T}_{\mathbf{1}, \mathbf{p A H F e}} / \boldsymbol{T}_{\mathbf{1}, \mathbf{p A H}}$ \\
\hline 8.2 & 1.47 & 1.18 & 0.804 \\
6.0 & 1.22 & 1.10 & 0.900 \\
2.6 & 0.376 & 0.363 & 0.966 \\
2.0 & 0.485 & 0.452 & 0.932 \\
\hline
\end{tabular}

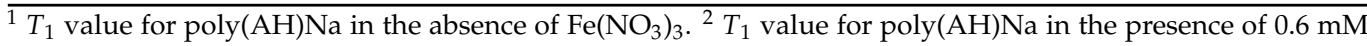
$\mathrm{Fe}\left(\mathrm{NO}_{3}\right)_{3}$.

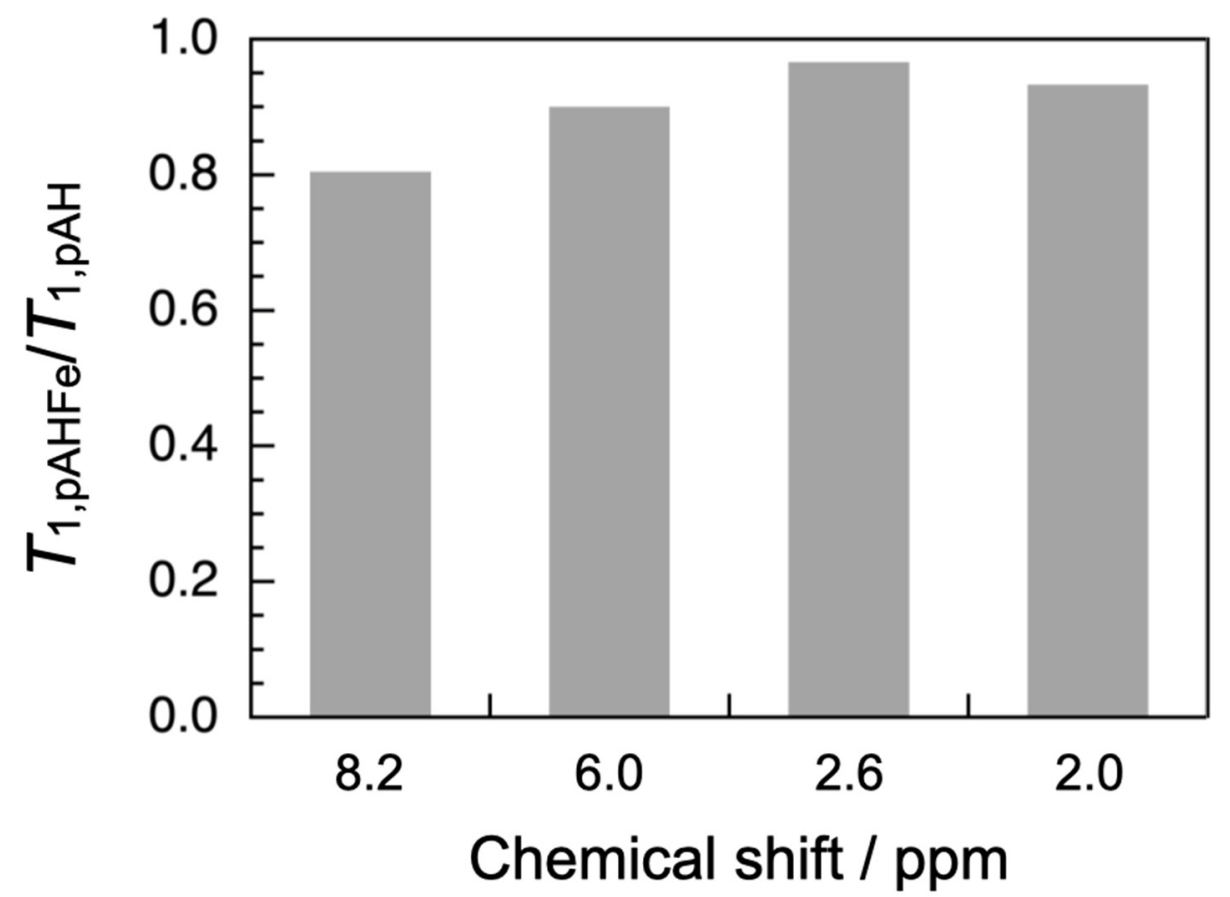

Figure 7. $T_{1, \mathrm{pAHFe}} / T_{1, \mathrm{pAH}}$ for ${ }^{1} \mathrm{H}$ NMR signals.

\section{Conclusions}

As a new polyanion with a dense 1,2,3-triazole backbone, poly(AH), was synthesized by $\mathrm{CuAAC}$ polymerization of $\mathrm{tBuAH}$ followed by hydrolysis of the $t$-Bu ester groups. The ${ }^{1} \mathrm{H}$ NMR and FTIR data confirmed the structure of poly(AH). Turbidimetric and potentiometric titration date indicated that poly( $\mathrm{AH})$ was well soluble at $\mathrm{pH}>7$, slightly soluble in the $\mathrm{pH}$ region of $7-4$, and practically insoluble in the regime of $\mathrm{pH}<4$. The apparent $\mathrm{p} K_{\mathrm{a}}$ at which $\alpha=0.5$ was estimated to be ca. 5.4 , which is larger than that of PAA ( $\left.\mathrm{p} K_{\mathrm{a}}=4.5\right)$, indicating that poly $(\mathrm{AH})$ is a weaker polyanion than PAA presumably because of the more hydrophobic backbone and linker of poly(AH). On the basis of PGSE NMR data, the hydrodynamic radii of poly(AH)Na were estimated to be ca. 3.4 and $3.7 \mathrm{~nm}$ at $\mathrm{pH} 9.0$ and 12.0, respectively, indicating that that poly( $\mathrm{AH})$ takes a conformation independent of $\mathrm{pH}$ under basic conditions. Since 1,2,3-triazole and carboxylate moieties may act as relatively soft and hard ligands, respectively, adsorption tests were thus performed using poly(AH)Na. The amounts adsorbed were $75.12 \pm 0.02,62.0 \pm 0.2,89.22 \pm 0.02$, and $98.57 \pm 0.03 \mathrm{mg} \mathrm{g}^{-1}$ for $\mathrm{Cu}^{2+}, \mathrm{Pb}^{2+}, \mathrm{Li}^{+}$, and $\mathrm{Fe}^{3+}$, respectively. These observations indicate that poly(AH)Na can be used as an adsorbent for metal ions, especially $\mathrm{Fe}^{3+}$ ion. The ratio of $T_{1}$ values for the ${ }^{1} \mathrm{H}$ NMR signals in the presence and absence of $0.6 \mathrm{mM} \mathrm{Fe}^{3+}$ was calculated to be $80.4 \%$ for the triazole proton at ca. $8.2 \mathrm{ppm}$, whereas those were $90.0-96.6 \%$ for the methine $(6.0 \mathrm{ppm})$ and methylene protons ( 2.6 and $2.0 \mathrm{ppm})$, indicating that $\mathrm{Fe}^{3+}$ ions are adsorbed more preferably onto the 1,2,3-triazole residues. On the basis of poly(AH), synthesis of sequence-controlled amphiphilic polymers is in progress. 
Author Contributions: Conceptualization, L.X. and A.H.; methodology, L.X., Y.K., and A.H.; software, L.X., Y.K., and A.H.; validation, L.X., Y.K., and A.H.; investigation, L.X., Y.K., and A.H.; resources, L.X. and A.H.; data curation, L.X., Y.K., and A.H.; writing-original draft preparation, L.X. and A.H.; writing-review and editing, Y.K. and A.H.; visualization, A.H.; supervision, A.H.; project administration, A.H.; funding acquisition, L.X. and A.H. All authors have read and agreed to the published version of the manuscript.

Funding: This work was partly supported by JSPS Kakenhi Grant Number JP26288061 (A.H.) and the Sasakawa Scientific Research Grant 2020-3009 from The Japan Science Society (L.X.).

Institutional Review Board Statement: Not applicable.

Informed Consent Statement: Not applicable.

Data Availability Statement: Not applicable.

Acknowledgments: We gratefully acknowledge Sadahito Aoshima and Arihiro Kanazawa, Department of Macromolecular Science, Graduate School of Science, Osaka University, for their kind support on SEC measurements and their valuable suggestions. We appreciate Hiroyasu Yamaguchi, Department of Macromolecular Science, Graduate School of Science, Osaka University, for allowing us to use the Fourier transform infrared (FTIR). We also thank to Yasuto Todokoro, Analytical Instrument Facility, Graduate School of Science, Osaka University, for his valuable suggestions on the PGSE NMR and ${ }^{1} \mathrm{H}$ nuclear spin-lattice relaxation time $\left(T_{1}\right)$ measurements.

Conflicts of Interest: The authors declare no conflict of interest.

\section{References}

1. Tripathy, S.; Kumar, J.; Nalwa, H.S. Applications of polyelectrolytes and theoretical models. In Handbook of Polyelectrolytes and Their Applications; American Scientific Publishers: Stevenson Ranch, CA, USA, 2002.

2. Nussinovitch, A. Water-Soluble Polymer Applications in Foods; Blackwell Science Ltd.: Oxford, UK, 2003.

3. Williams, P.A. Handbook of Industrial Water Soluble Polymers; Blackwell Publishing: Oxford, UK, 2007.

4. Rivas, B.L.; Pereira, E.; Maureira, A. Functional water-soluble polymers: Polymer-metal ion removal and biocide properties. Polym. Int. 2009, 58, 1093-1114. [CrossRef]

5. Rivas, B.L.; Pereira, E.D.; Palencia, M.; Sánchez, J. Water-soluble functional polymers in conjunction with membranes to remove pollutant ions from aqueous solutions. Prog. Polym. Sci. 2011, 36, 294-322. [CrossRef]

6. Kadajji, V.G.; Betageri, G.V. Water soluble polymers for pharmaceutical applications. Polymers 2011, 3, 1972. [CrossRef]

7. Dehaen, W.; Bakulev, V.A. Chemistry of 1,2,3-Triazoles; Springer: Cham, Switzerland, 2015.

8. Schulze, B.; Schubert, U.S. Beyond click chemistry-supramolecular interactions of 1,2,3-triazoles. Chem. Soc. Rev. 2014, 43, 2522-2571. [CrossRef] [PubMed]

9. Li, Y.; Huffman, J.C.; Flood, A.H. Can terdentate 2,6-bis(1,2,3-triazol-4-yl)pyridines form stable coordination compounds? Chem. Commun. 2007, 2692-2694. [CrossRef] [PubMed]

10. Meudtner, R.M.; Hecht, S. Responsive backbones based on alternating triazole-pyridine/benzene copolymers: From helically folding polymers to metallosupramolecularly crosslinked gels. Macromol. Rapid Commun. 2008, 29, 347-351. [CrossRef]

11. Pourghaz, Y.; Dongare, P.; Thompson, D.W.; Zhao, Y. Click functionalized poly( $p$-phenylene ethynylene)s as highly selective and sensitive fluorescence turn-on chemosensors for $\mathrm{Zn}^{2+}$ and $\mathrm{Cd}^{2+}$ ions. Chem. Commun. 2011, 47, 11014-11016. [CrossRef]

12. Mishra, V.; Jung, S.-H.; Park, J.M.; Jeong, H.M.; Lee, H.-I. Triazole-containing hydrogels for time-dependent sustained drug release. Macromol. Rapid Commun. 2014, 35, 442-446. [CrossRef]

13. Wu, J.; Liu, W.; Han, H.; Sun, R.; Xie, M.; Liao, X. Hyperbranched poly(triazole) with thermal and metal ion dual stimuliresponsiveness. Polym. Chem. 2015, 6, 4801-4808. [CrossRef]

14. Ghosh, K.; Panja, A.; Panja, S. Cholesterol appended bis-1,2,3-triazoles as simple supramolecular gelators for the naked eye detection of $\mathrm{Ag}^{+}, \mathrm{Cu}^{2+}$ and $\mathrm{Hg}^{2+}$ ions. New J. Chem. 2016, 40, 3476-3483. [CrossRef]

15. Huisgen, R. 1,3-Dipolar cycloadditions. past and future. Angew. Chem. Int. Ed. Engl. 1963, 2, 565-598. [CrossRef]

16. Abboud, J.-L.M.; Foces-Foces, C.; Notario, R.; Trifonov, R.E.; Volovodenko, A.P.; Ostrovskii, V.A.; Alkorta, I.; Elguero, J. Basicity of $\mathrm{N}$-H- and N-methyl-1,2,3-triazoles in the gas phase, in solution, and in the solid state-An experimental and theoretical study. Eur. J. Org. Chem. 2001, 2001, 3013-3024. [CrossRef]

17. Kolb, H.C.; Sharpless, K.B. The growing impact of click chemistry on drug discovery. Drug Discov. Today 2003, 8, $1128-1137$. [CrossRef]

18. Tornøe, C.W.; Christensen, C.; Meldal, M. Peptidotriazoles on solid phase: [1,2,3]-Triazoles by regiospecific copper(I)-catalyzed 1,3-dipolar cycloadditions of terminal alkynes to azides. J. Org. Chem. 2002, 67, 3057-3064. [CrossRef] [PubMed]

19. Rostovtsev, V.V.; Green, L.G.; Fokin, V.V.; Sharpless, K.B. A stepwise huisgen cycloaddition process: Copper(I)-catalyzed regioselective "ligation" of azides and terminal alkynes. Angew. Chem. Int. Ed. 2002, 41, 2596-2599. [CrossRef] 
20. Fazio, F.; Bryan, M.C.; Blixt, O.; Paulson, J.C.; Wong, C.-H. Synthesis of sugar arrays in microtiter plate. J. Am. Chem. Soc. 2002, 124, 14397-14402. [CrossRef]

21. Kolb, H.C.; Finn, M.G.; Sharpless, K.B. Click chemistry: Diverse chemical function from a few good reactions. Angew. Chem. Int. Ed. 2001, 40, 2004-2021. [CrossRef]

22. Lahann, J. Click Chemistry for Biotechnology and Materials Science; Wiley \& Sons: Chichester, UK, 2009.

23. Qin, A.; Lam, J.W.Y.; Tang, B.Z. Click polymerization. Chem. Soc. Rev. 2010, 39, 2522-2544. [CrossRef]

24. Huang, D.; Liu, Y.; Qin, A.; Tang, B.Z. Recent advances in alkyne-based click polymerizations. Polym. Chem. 2018, 9, $2853-2867$. [CrossRef]

25. Atanase, L.I.; Glaied, O.; Riess, G. Crystallization kinetics of PCL tagged with well-defined positional triazole defects generated by click chemistry. Polymer 2011, 52, 3074-3081. [CrossRef]

26. Wei, Q.; Wang, J.; Shen, X.; Zhang, X.A.; Sun, J.Z.; Qin, A.; Tang, B.Z. Self-healing hyperbranched poly(aroyltriazole)s. Sci. Rep. 2013, 3. [CrossRef]

27. Hashidzume, A.; Nakamura, T.; Sato, T. Copper-catalyzed azide-alkyne cycloaddition oligomerization of 3-azido-1-propyne derivatives. Polymer 2013, 54, 3448-3451. [CrossRef]

28. Nakano, S.; Hashidzume, A.; Sato, T. Quarternization of 3-azido-1-propyne oligomers obtained by copper(I)-catalyzed azidealkyne cycloaddition polymerization. Beilstein J. Org. Chem. 2015, 11, 1037-1042. [CrossRef]

29. Yang, Y.; Mori, A.; Hashidzume, A. Emission properties of diblock copolymers composed of poly(ethylene glycol) and dense 1,2,3-triazole blocks. Polymers 2019, 11, 1086. [CrossRef] [PubMed]

30. Yang, Y.; Hashidzume, A. A new associative diblock copolymer of poly(ethylene glycol) and dense 1,2,3-triazole blocks: Selfassociation behavior and thermoresponsiveness in water. Macromol. Chem. Phys. 2019, 220, 1900317. [CrossRef]

31. Yang, Y.; Kamon, Y.; Lynd, N.A.; Hashidzume, A. Self-healing thermoplastic elastomers formed from triblock copolymers with dense 1,2,3-triazole blocks. Macromolecules 2020, 53, 10323-10329. [CrossRef]

32. Yamasaki, S.; Kamon, Y.; Xu, L.; Hashidzume, A. Synthesis of dense 1,2,3-triazole polymers soluble in common organic solvents. Polymers 2021, accepted.

33. Stejskal, E.O.; Tanner, J.E. Spin diffusion measurements: Spin echoes in the presence of a time-dependent field gradient. J. Chem. Phys. 1965, 42, 288-292. [CrossRef]

34. Tanner, J.E.; Stejskal, E.O. Restricted self-diffusion of proteins in colloidal systems by the pulse-gradient, spin-echo method. J. Chem. Phys. 1968, 49, 1768-1777. [CrossRef]

35. Stilbs, P. Fourier transform pulsed-gradient spin-echo studies of molecular diffusion. Prog. Nucl. Magn. Reson. Spectrosc. 1987, 19, 1-45. [CrossRef]

36. Morris, K.F.; Stilbs, P.; Johnson, C.S. Analysis of mixtures based on molecular size and hydrophobicity by means of diffusionordered 2D NMR. Anal. Chem. 1994, 66, 211-215. [CrossRef]

37. Huo, R.; Wehrens, R.; Van Duynhoven, J.; Buydens, L.M.C. Assessment of techniques for DOSY NMR data processing. Anal. Chim. Acta 2003, 490, 231-251. [CrossRef]

38. Erdmann, K.; Gutsze, A. Model of proton longitudinal magnetic relaxation in hydrated crosslinked poly(methacrylic acid). Colloid Polym. Sci. 1987, 265, 667-673. [CrossRef]

39. Raby, P.; Budd, P.M.; Heatley, F.; Price, C. Nuclear magnetic relaxation of $\alpha-{ }^{13}$ C nuclei of helical poly ( $\gamma$-hexyl-L-glutamate) and poly ( $\gamma$-benzyl-L-glutamate). J. Polym. Sci. Part B Polym. Phys. 1991, 29, 451-456. [CrossRef]

40. Brereton, M.G.; Ward, I.M.; Boden, N.; Wright, P. Nature of the proton NMR transverse relaxation function of polyethylene melts. 1. Monodispersed polyethylenes. Macromolecules 1991, 24, 2068-2074. [CrossRef]

41. Das, K.K.; Somasundaran, P. Ultra-low dosage flocculation of alumina using polyacrylic acid. Colloids Surf. A 2001, 182, 25-33. [CrossRef]

42. Hashidzume, A.; Morishima, Y.; Szczubiałka, K. Amphiphilic polyelectrolytes. In Handbook of Polyelectrolytes and Their Applications; Tripathy, S.K., Kumar, J., Nalwa, H.S., Eds.; American Scientific Publishers: Stevenson Ranch, CA, USA, 2002; Volume 2, pp. 1-63.

43. Saravanan, N.; Yusuff, K.K.M. New complexes of iron(III), cobalt(II), nickel(II) and copper(II) with 2-phenyl-1,2,3-triazole-4carboxalidene-2-aminophenol. Transit. Met. Chem. 1996, 21, 464-468. [CrossRef]

44. You, X.; Wei, Z. Two multidentate ligands utilizing triazolyl, pyridinyl and phenolate groups as donors for constructing dinuclear copper(II) and iron(III) complexes: Syntheses, structures, and electrochemistry. Inorg. Chim. Acta 2014, 423, 332-339. [CrossRef] 